\title{
Evaluation of the Usefulness of Selective Chromogenic Agar Medium (ChromID VRE) and Multiplex PCR Method for the Detection of Vancomycin-resistant Enterococci
}

\author{
Do-Hoon Kim, M.D., Jae-Hee Lee, M.D., Jung-Sook Ha, M.D., Nam-Hee Ryoo, M.D., Dong-Seok Jeon, M.D., \\ and Jae-Ryong Kim, M.D.
}

Department of Laboratory Medicine, Keimyung University School of Medicine, Daegu, Korea

\begin{abstract}
Background : Accurate and early detection of vancomycin-resistant enterococci (VRE) is critical for controlling nosocomial infection. In this study, we evaluated the usefulness of a selective chromogenic agar medium and of multiplex PCR for detection of VRE, and both these techniques were compared with the conventional culture method for VRE detection.

Methods : We performed the following 3 methods for detecting VRE infection in stool specimens: the routine culture method, culturing in selective chromogenic agar medium (chromID VRE, bioMérieux, France), and multiplex PCR using the Seeplex ${ }^{\circledR}$ VRE ACE Detection kit (Seegene Inc., Korea) with additional PCR for vanC genes.

Results : We isolated 109 VRE strains from 100 stool specimens by the routine culture method. In chromID VRE, all the isolates showed purple colonies, including Enterococcus gallinarum and E. raffinosus, which were later identified using the Vitek card. All VRE isolates were identified by the multiplex PCR method; 100 were vanA-positive E. faecium, 8 were vanA- and vanC-1-positive $E$. gallinarum, and 1 was vanA-positive E. raffinosus.

Conclusions : For VRE surveillance, culturing the isolates in chromID VRE after broth enrichment appears to be an accurate, rapid, and easy method for routine screening test. Multiplex PCR is relatively expensive and needs skilled techniques for detecting VRE, but it can be an auxiliary tool for rapid detection of genotype during a VRE outbreak. (Korean J Lab Med 2010;30:631-6)
\end{abstract}

Key Words : VRE, Chromogenic agar, PCR

\section{서 론}

장알균은 조건무산소성 그람양성알균으로 다양한 환경에 대한 강한 저항력을 가지므로 자연에 흔히 존재하며, 동물과 사람의 장내 정상균 무리이다[1]. 병독성이 낮아 임상적으로 큰 의의를 두지 않았던 장알균은, 1986년 유럽에서 vancomycin 내성 장 알균(vancomycin-resistant enterococci, VRE)이 처음 보고

Received: April 28, 2010

Revision received : July 24, 2010

Accepted : October 6, 2010

Corresponding author : Nam-Hee Ryoo, M.D. Department of Laboratory Medicine, Keimyung University School of Medicine, 194 Dongsan-dong, Jung-gu, Daegu 700-712, Korea

Tel : +82-53-250-7950, Fax : +82-53-250-7275

E-mail : nhryoo@dsmc.or.kr

ISSN 1598-6535 (C) The Korean Society for Laboratory Medicine
된 이후 $\mathrm{VRE}$ 는 세계적으로 중요한 병원균으로 보고되어 왔고 주로 균혈증이나 요로감염, 심내막염, 그리고 골수염 등과 같은 다양한 기회감염을 일으킨다[1, 2]. 미국에서는 약 $40 \%$ 가 VRE 로 분리된 것으로 보고하였고, 영국(10.4\%), 이탈리아(19.6\%) 등 유럽에서도 높은 VRE의 유병률을 나타내었다[3, 4]. 한국내성 세균조사단(KONSAR)의 조사에 의하면 Enterococcus faecium 의 vancomycin에 대한 내성률이 1997년 2.9\%에서 2006년은 $16 \%$ 로 증가한 것으로 나타났다[5]. 본원의 경우도 $E$. faecium의 vancomycin 내성률이 2008년 31.1\%에서 2009년은 37.2\%로 지속적으로 증가한 것으로 나타났다.

$\mathrm{VRE}$ 의 정확한 조기 검출은 병원 내 감염전파의 추적과 관리 를 위해서뿐만이 아니라, 반코마이신 내성 황색 포도알균(vancomycin-resistant Staphylococcus aureus, VRSA)의 출현 을 막기 위해서도 중요하다[2, 6]. 또한 VRE가 분리되는 환자에 
있어서는 장내 집락화의 유무를 조기에 검출하여 사람 간의 전파 방지 및 격리를 해야 한다. 그러므로 대변에서의 VRE 선별검사 는 $\mathrm{VRE}$ 의 조기 검출을 위한 여러 가지 선별배지를 이용하는 것 과 최근에 신속증균 $\mathrm{PCR}$ 법을 사용하는 방법 등이 소개되고 있 다[1, 4, 6-11]. 이에 본 연구는 VRE 감시배양을 위해 의뢰된 대변검체를 고식적인 배양법과 더불어 고체 선택배지 사용법, 그 리고 다중 PCR법으로 신속 동정을 동시에 시행한 후 각 방법에 대해 비교 평가를 하고자 하였다.

\section{대상 및 방법}

\section{1. 대상 검체}

본원에서 2009년 8월부터 2010년 2월까지 VRE 감시배양을 위해 진단검사의학과 미생물검사실로 의뢰된 대변 검체 총 109 개를 대상으로 하였다.

\section{2. 방법}

의뢰된 대변 검체를 우선 자가 제조한 액체 배지 $(6 \mu \mathrm{g} / \mathrm{mL}$ 의 vancomycin이 들어 있는 enterococcosel broth)에 접종한 후 에 $37^{\circ} \mathrm{C}$ 에서 증균 배양 후 1 일째와 2 일째 각각 배지의 색상 변 화를 판독하였다 $[4,8,10]$. 그중 검게 변한 배지를 선별하여 $\mathrm{VRE}$ 검출을 위해 아래와 같은 3 가지의 방법을 병행하였다.

먼저 고식적인 배양법을 사용하였는데, 검게 변한 액체 배지 를 혈액한천배지에 접종한 후 $37^{\circ} \mathrm{C}$ 에서 하룻밤 배양하였다. 배 지에 자란 균 집락을 그람 염색을 하여 그람양성알균인 것을 확 인하고 catalase 시험 음성임을 확인하였다. 이후 Vitek $2 \mathrm{GP}$ 카드와 AST-P600 카드(bioMérieux VITEK, Hazelwood, MO, USA)를 사용하여 동정과 항균제감수성검사를 하였다. Enterococcus gallinarum 또는 Enterococcus casseliflavus이 동정 되었을 때에는 운동성과 색소생성 시험을 시행하여 감별하였다. 균 동정 시 최종 확인이 필요할 경우, $16 \mathrm{~S} r \mathrm{rNA}$ 유전자에 대한 전체 염기서열분석(MACROGEN, Seoul, Korea)을 실시하였다.

두 번째 방법으로는 chromID VRE (bioMérieux, Marcy-l' Etoile, France) 고체 선택배지를 사용하였다. 액체 배지가 검게 변한 것을 확인한 후 내용물을 chromID VRE에 접종하고 $37^{\circ} \mathrm{C}$ 에서 1 일 배양 후 특정 색소를 띠는 전형적인 장알균 집락을 $\mathrm{VRE}$ 로 1차 동정하였다(보라색: E. faecium, 청록색: Enterococcus faecalis). 그람 염색과 catalase 시험 후 최종적으로 Vitek $2 \mathrm{GP}$ 카드와 AST-P600 카드(bioMérieux VITEK)를 사용하여 생화
학적 동정과 항균제감수성검사를 시행하였다.

세 번째 검출 방법인 다중 $\mathrm{PCR}$ 은 $\operatorname{van} A$ 와 $\operatorname{vanB}$ 유전자에 특 이적인 시발체를 이용하는 Seeplex ${ }^{\circledR}$ VRE ACE Detection 키 트(Seegene Inc., Seoul, Korea)를 사용하였다. 검게 변한 액체 배지 $50 \mu \mathrm{L}$ 와 키트에 포함된 DNA extraction solution $100 \mu \mathrm{L}$ 를 섞은 뒤 끓는 물에 10 분간 중탕 후 $13,000 \mathrm{rpm}$ 으로 5 분간 원심분리하여 $\mathrm{DNA}$ 를 추출하였다. 이후 Seeplex ${ }^{\circledR} \mathrm{VRE} \mathrm{ACE}$ Detection키트를 사용하여 총 PCR 반응액 $20 \mu \mathrm{L}$ (DNA $1 \mu \mathrm{L}$, $5 \times \mathrm{VRE}$ primer $4 \mu \mathrm{L}$, 8-methoxypsoralen $3 \mu \mathrm{L}, 2 \times \mathrm{Mul}-$ tiplex Master Mix $10 \mu \mathrm{L}$ )를 제조한 다음 PCR 반응을 실시하였 다. $\mathrm{PCR}$ 반응은 $94^{\circ} \mathrm{C}$ 에서 15 분 반응 후 $94^{\circ} \mathrm{C} 30$ 초, $60^{\circ} \mathrm{C} 1$ 분, $72^{\circ} \mathrm{C} 1$ 분의 반응을 35 회 반복하였고 최종 연장반응을 $72^{\circ} \mathrm{C}$ 에서 10 분간 시행했다. 최종산물은 검체 간 상호 오염을 방지하기 위 해 20분간 자외선(365 nm)을 조사한 후에 ethidium bromide 를 포함한 $2 \%$ 아가로오즈겔에서 전기영동하여 $360 \mathrm{bp}(\operatorname{van} A)$ 와 $250 \mathrm{bp}$ ( $\operatorname{vanB}$ )에 해당하는 밴드의 유무를 판독하였다. 양성 대조균주로 E. faecium BM4147 ( $\operatorname{vanA}$ ), 음성대조균주로 $E$. faecalis ATCC 29212 를 사용하였다.

균 동정 결과 $E$. faecium, $E$. faecalis 이외의 균(E. gallinarum, E. casseliflavus, Enterococcus flavuscence)이 나왔을 때는 Table 1에 제시한 시발체를 추가로 이용하여 $\operatorname{vanC}-1$, $\operatorname{vanC}-2$ 및 $\mathrm{vanC}-3$ 유전자의 유무를 확인하였다[2, 4]. PCR은 추출한 DNA 0.5 $\mu \mathrm{L}$, 시발체(20 pmol) $2 \mu \mathrm{L}$, Smart Taq Pre-Mix (Solgent, Daegeon, Korea) $17.5 \mu \mathrm{L}$ 를 혼합한 반응액을 $94^{\circ} \mathrm{C}$ 에서 5 분 반응 후 $94^{\circ} \mathrm{C} 30$ 초, $45^{\circ} \mathrm{C} 45$ 초, $72^{\circ} \mathrm{C} 1$ 분의 반응을 30 회 반 복하였고 최종 연장반응을 $72^{\circ} \mathrm{C}$ 에서 5 분간 시행했다. 증폭된 산 물은 전기영동 후 자외선 조영하에 판독하였다.

\section{결 과}

총 109검체 가운데 선택 증균 배지인 enterococcosel broth가 검게 변하지 않은 8 개의 검체를 제외한 나머지 101검체를 대상 으로 실험을 진행하였다. 고식적인 배양법으로 최종 동정한 결과

Table 1. Primer sequences that were used in PCR for vancomycinresistance genotyping

\begin{tabular}{lccc}
\hline Amplified gene & & Primer sequence $\left(5^{\prime}{ }^{\prime} 3^{\prime}\right)$ & size (bp) \\
\hline vanC-1 & (F) & GGTATCAAGGAACCTC & 822 \\
& (R) & CTTCCGCCATCATAGCT & \\
vanC-2, vanC-3 & (F) & CTCCTACGATCTCTTG & 439 \\
& (R) & CGAGCAAGACCTTAAG & \\
\end{tabular}

Abbreviations: $F$, forward; $R$, reverse. 
91검체(90.1\%)에서는 E. faecium만 동정되었고, 9검체(8.9\%) 에서 두 균주가 함께 동정되었는데 그중 8검체(7.9\%)는 E. faecium과 E. gallinarum, 1검체(1.0\%)는 E. faecium과 Enterococcus raffinosus가 동정되었다. 그리고 1검체(1.0\%)에서 $E$. casseliflavus만 동정되었으며 E. faecalis는 분리되지 않았다. Vancomycin에 감수성을 가진 E. casseliflavus가 동정된 1검체 를 제외한 100 개의 검체에서 총 109 균주의 VRE가 분리되었다 (Table 2).

각 균주에 대한 항균제 감수성검사 결과, vancomycin과 teicoplanin에 대한 MIC는 E. faecium 88주(80.7\%)와 E. gallinarum 8주(7.3\%)에서 $32 \mu \mathrm{g} / \mathrm{mL}$ 이상으로 고도내성을 나타냈다. E. faecium 8주(7.3\%)는 vancomycin에 대한 MIC가 $32 \mu \mathrm{g} / \mathrm{mL}$ 이상으로 고도내성을 보였지만, teicoplanin에 대한 MIC는 16 $\mu \mathrm{g} / \mathrm{mL}$ 로 중등도의 내성을 보였다. 나머지 4 주의 E. faecium

Table 2. Results of routine culture, chromID, and PCR method of studied isolates

\begin{tabular}{|c|c|c|c|c|}
\hline $\begin{array}{l}\text { Routine } \\
\text { culture }\end{array}$ & $\begin{array}{c}\mathrm{N} \text { of isolates } \\
\text { (\%) }\end{array}$ & $\begin{array}{c}\text { ChromID } \\
\text { (color) }\end{array}$ & $\begin{array}{c}\text { Phenotype } \\
\text { (N) }\end{array}$ & $\begin{array}{l}\text { Genotype } \\
\text { (by PCR) }\end{array}$ \\
\hline E. faecium & $100(91.7)$ & Purple & $\begin{array}{l}\operatorname{Van} A(88) \\
\operatorname{VanB}(12)\end{array}$ & $\operatorname{van} A$ \\
\hline E. gallinarum & $8(7.3)$ & Purple & $\operatorname{VanA}(8)$ & vanA with vanC-1 \\
\hline E. raffinosus & $1(0.9)$ & Purple & $\operatorname{Van} A(1)$ & $\operatorname{van} A$ \\
\hline E. casseliflavus & s $1(0.9)$ & $N G$ & NT & NT \\
\hline Total & $109^{*}$ & & & \\
\hline
\end{tabular}

*Isolates counted without E. casseliflavus.

Abbreviations: E. faecium, Enteroccus faecium; E. gallinarum, Enteroccus gallinarum; E. raffinosus, Enteroccus raffinosus; E. casseliflavus, Enteroccus casseliflavus; NG, no growth; NT, not tested (due to the susceptibility to vancomycin).
(3.7\%)은 vancomycin에 대한 MIC가 $32 \mu \mathrm{g} / \mathrm{mL}$ 이상으로 나타 났지만, teicoplanin에 대한 $\mathrm{MIC}$ 는 $4 \mu \mathrm{g} / \mathrm{mL}$ 로 감수성을 보였다. E. raffinosus 1주의 경우 항균제 감수성 시험을 vancomycin $30 \mu \mathrm{g}$, teicoplanin $30 \mu \mathrm{g}$ 디스크를 써서 실시한 결과, 억제대 의 지름이 vancomycin과 teicoplanin 모두 $6 \mathrm{~mm}$ 였다. E. casseliflavus로 동정된 1주의 경우, vancomycin에 대한 MIC가 4 $\mu \mathrm{g} / \mathrm{mL}$, teicoplanin은 $\leq 1 \mu \mathrm{g} / \mathrm{mL}$ 이었다.

ChromID VRE 배지를 이용한 경우, 전혀 균이 자라지 않은 1검체를 제외한 나머지 100검체(99.0\%)에서 모두 E. faecium 을 의미하는 보라색의 전형적인 균집락이 관찰되었다. ChromID $\mathrm{VRE}$ 배지에서 자라지 않은 1검체는 고식적인 배양법에서 확인 한 결과, vancomycin에 감수성을 보인 E. casseliflavus였다.

Seeplex ${ }^{\circledR}$ VRE ACE Detection 키트를 이용한 PCR에서 109 주의 모든 $\mathrm{VRE}$ 균주에서 $\operatorname{vanA}$ 유전자형을 나타내었다. 그중 고식적인 배양법으로 동정하여 E. faecium 이외의 균으로 확인된 9주(E. gallinarum 8주+E. raffinosus 1주)를 대상으로 vanC-1, $\operatorname{vanC}-2$ 와 $\operatorname{vanC}-3$ 유전자를 포함한 $\mathrm{PCR}$ 을 추가로 실시한 결과, 8주의 E. gallinarum는 vanC-1 유전자도 양성이었다(Fig. 1).

각 검사 방법에 따른 총 검사 소요 시간을 비교하여 보면, 고 식적인 배양법의 경우 선택 액체 배지에 접종할 때부터 최종결 과까지 3일 정도 소요되었고, chromID VRE는 2일째에 VRE 를 검출할 수 있었다. 다중 PCR법은 액체배지에 증균 후 바로 검사에 들어가면 1 일 이내에 검사결과를 얻을 수가 있었다.

\section{고 찰}

$\mathrm{VRE}$ 는 국내의 중환자실이나 혈액종양병동 등에서 토착화되
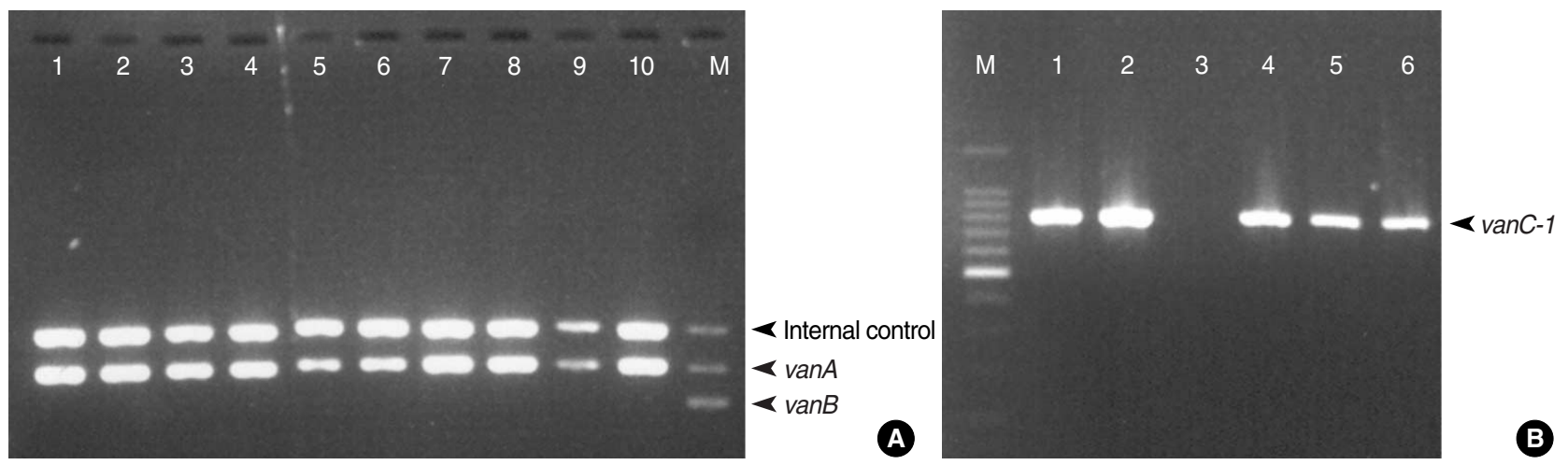

Fig. 1. Agarose gel electrophoresis of PCR products: Lane M; VRE size marker, Lanes 1, 2, 4-6; E. gallinarum, Lane 3; E. raffinosus, Lanes 7-10; E. faecium. (A) PCR products of clinical isolates of this study using Seeplex ${ }^{\circledR}$ VRE ACE Detection kit: only vanA is observed in all the lanes. (B) PCR products with vanC-1 primer.

Abbreviations: VRE, vancomycin-resistant enterococci; E. gallinarum, Enteroccus gallinarum; E. raffinosus, Enteroccus raffinosus; E. faecium, Enteroccus faecium. 
어 가고 있는 실정이다. $\mathrm{VRE}$ 의 유행과 전파를 막기 위한 감염 관리지침이 있으나 국내의 모든 병원에서 적용하기가 어려운 실 정이고 다각적 감염관리를 시행하여도 근절하기 힘든 병원감염 의 주요 다제내성균이다[12]. 특히 VRE는 메티실린 내성 황색 포도알균(methicillin-resistant Staphylococcus aureus, $\mathrm{MRSA}$ )으로 내성 유전자를 전달할 수 있기 때문에, MRSA가 토착화되어 있는 국내 병원에서는 $\mathrm{VRE}$ 의 신속하고 정확하면서 도 비용효율적인 검출이 매우 중요하다.

$\mathrm{VRE}$ 의 신속한 검출을 위하여 선택 액체배지에 증균을 시키면 그람음성막대균이나 효모균 등에 의한 오염이 억제되므로 검체 를 직접 고형배지에 접종하거나 $\mathrm{PCR}$ 을 시행하는 것보다 결과가 우수하다고 보고하였다 $[1,4,8,10,13]$. 이에 본 연구는 모든 검 체를 선택 액체배지에서 증균시킨 후 각 방법의 실험을 진행하 도록 하였다. 선택 액체배지에서 검은색으로 변한 검체들 중 1 검체에서 고식적인 배양법 결과 vancomycin에 감수성인 E. casseliflavus이 자라서 위양성 VRE로 분류하였다. 이 검체를 chro$\mathrm{mID} \mathrm{VRE}$ 에 접종한 결과 음성이었는데, 이는 선택 액체배지와 chromID VRE의 vancomycin 함유량의 차이(선택 액체 배지: $6 \mu \mathrm{g} / \mathrm{mL}$, chromID VRE: $8 \mu \mathrm{g} / \mathrm{mL}$ ) 때문이었다. 이번 연구에 서 $\mathrm{VRE}$ 양성률이 통상적인 $\mathrm{VRE}$ 양성률보다 높게 나타난 것은 이전에 VRE가 반복적으로 동정이 되었던 환자의 VRE 선별검 사가 의뢰된 검체만을 대상으로 하였기 때문이다.

ChromID VRE 배지를 이용한 경우, 보라색으로 자란 균주들 은 모두 E. faecium으로 생각되었으나, 혈액한천배지에 계대 배양하여 고식적 배양법으로 동정한 결과 9 개의 검체에서 $E$. faecium과 $E$. gallinarum 혹은 E. faecium과 E. raffinosus가 같이 존재하는 것으로 나타났다. Delmas 등[4]은 chromID VRE 배지에서 E. faecium 집락의 모양이 효모균과 그람음성막대균 의 집락 모양과 비슷하여 혼동될 수 있지만 E. gallinarum, E. casseliflavus, 그리고 그람양성막대균의 모양과는 달라서 구분 이 가능하다고 하였다. ChromID VRE 배지에서 자란 균 집락 의 모양을 면밀히 살펴 본 결과, 각 장알균 균종들 간의 차이를 육안으로 식별해내기는 어려웠지만 고식적 배양법과 다중 PCR 법을 시행한 결과 chromID VRE 배지에서 보라색으로 자란 모 든 균주가 $\operatorname{vanA}$ 유전자를 가진 VRE로 나타났다. 따라서 혈액 한천배지에 계대배양하여 고식적인 배양법이나 장알균 간이 동 정법으로 확인하지 않고서도 chromID VRE 배지만으로 vancomycin 내성 유무를 빠르고 정확하게 선별하기에 충분한 것 으로 생각되었다.

한편, Seeplex ${ }^{\circledR}$ VRE ACE Detection 키트를 사용하여 PCR 을 시행한 결과 모두 음성으로 나왔으나, Drews 등[14]이 제시
한 방법을 인용하여 핵산을 다시 추출하고 주형 DNA 농도를 지 침보다 3 배 희석하여 $\mathrm{PCR}$ 을 시행한 결과 위음성 문제가 해결되 었다. 본 연구에서 분리된 109 주의 VRE 균주는 모두 $\operatorname{vanA}$ 유 전자를 가진 것으로 나타났다. 동시에 분리된 E. gallinarum 8 주의 경우, 모두 $\operatorname{van} A$ 와 $\operatorname{vanC}-1$ 유전자형을 함께 지닌 vancomycin 고도 내성 균주로 나타났다. E. gallinarum이 분리된 환자들을 분석한 결과, 대부분이 장기 입원한 환자들로 각각 다 른 병동에 입원하고 있었으며 $\mathrm{VRE}$ 에 의한 감염이 없는 상태이 었으므로 $\mathrm{VRE}$ 의 집락화로 판단된다. 또한, E. faecium이 계속 해서 나오던 상태에서 $\operatorname{van} A$ 를 가진 E. gallinarum이 분리되 었으므로 Hsueh 등[15]과 Sung 등[16]의 주장과 같이 종간에 $\operatorname{vanA}$ 유전자의 수평전파가 이루어진 것으로 생각된다.

분리된 VRE 균주들의 표현형을 분석한 결과, VanA가 97 주, $\operatorname{VanB}$ 가 12 주로 확인되었다. $\operatorname{van} A$ 유전자형에 $\operatorname{VanB}$ 표현형을 가진 VRE가 최근 몇 년간 아시아에서 증가하는 추세를 보이고, 국내에서는 vanS 유전자의 코돈 영역에 IS $1216 V$ 를 가지는 것 으로 인해 teicoplanin에 대한 내성 변이가 일어난 것으로 설명 하는 보고도 있다[17]. 본원의 경우 이번 연구를 통하여 $\operatorname{vanA}$ 유전자형에 $\operatorname{VanB}$ 표현형을 가진 VRE가 꾸준히 분리되는 것으 로 나타났으므로 추후에 타 병원을 포함하여 더 많은 검체들을 대상으로 한 분자역학적 연구를 통하여 지역적인 확인이 필요할 것으로 생각된다.

결론적으로, VRE 감시배양에서 선택 액체배지에서 증균배양 이후 chromID VRE 배지를 이용하는 방법은 집락의 색깔로 $\mathrm{VRE}$ 를 확인하므로 쉽고 정확하게 구분할 수 있으므로 검사실 의 통상적인 선별검사로서 비교적 빠르고 비용 효율적인 방법 으로 생각된다. 다중 PCR법은 고비용, 인력소모적인 방법이나 검사결과의 확인이 하루 만에 가능하고 민감한 방법으로 내인성 저도내성 장알균의 표현형이 고도내성을 보일 때와 $\mathrm{VRE}$ 대유 행시 내성 유전자형의 정확한 확인으로 신속한 감염관리를 대 처할 수 있는 방법으로 유용하리라 생각된다.

\section{요 약}

배경 : VRE의 정확한 조기 검출은 병원 내 감염전파의 추적 과 관리를 위해 매우 중요하다. 본 연구에서는 색소생산성 고체 선택배지와 다중 $\mathrm{PCR}$ 에 대한 평가를 시행하였고 각 방법을 $\mathrm{VRE}$ 검출을 위한 고식적인 배양법과 비교 평가하였다.

방법 : 대변 검체들에 대해 세 가지 방법으로 $\mathrm{VRE}$ 동정시험을 실시하였다. 고식적인 배양법과 chromID VRE (bioMérieux, France) 배지를 이용한 색소생산성 고체 선택배지법, 그리고 
Seeplex ${ }^{\circledR}$ VRE ACE Detection 키트(Seegene Inc., Korea)를 이용한 다중 $\mathrm{PCR}$ 과 $\operatorname{vanC}$ 유전자에 대한 추가적인 $\mathrm{PCR}$ 을 $\mathrm{VRE}$ 검출을 위해 시행하였다.

결과 : 고식적인 배양법에 의해 100 검체에서 총 109 주의 VRE 균주를 분리하였다. ChromID VRE를 사용한 결과, 나중에 Vitek 카드에서 Enterococcus gallinarum과 Enterococcus raffinosus로 동정된 균주를 포함한 모든 균주서 보라색 균집락을 나 타냈다. 다중 $\mathrm{PCR}$ 시행 결과 모든 $\mathrm{VRE}$ 균주들을 검출할 수 있 었고 그중 100주는 vanA 유전자형을 가진 Enterococcus faecium, 8주는 vanA와 $\operatorname{vanC}-1$ 유전자형을 함께 지닌 E. gallinarum, 그리고 1주는 vanA 유전자형을 가진 E. raffinosus였다.

결론 : VRE 감시배양을 위해서, 액체배지에서 증균배양 이후 chromID VRE 배지를 이용하는 것은 검사실의 통상적인 선별 검사로서 정확하고 빠르면서도 쉬운 방법이다. 다중 $\mathrm{PCR}$ 법은 $\mathrm{VRE}$ 검출을 위해 상대적으로 높은 비용과 숙련된 기술을 요하 지만, VRE 대유행 시 유전자형의 빠른 검출을 위한 유용한 보 조도구로 생각된다.

\section{참고문헌}

1. Cuzon G, Naas T, Fortineau N, Nordmann P. Novel chromogenic medium for detection of vancomycin-resistant Enterococcus faecium and Enterococcus faecalis. J Clin Microbiol 2008;46:2442-4.

2. Song JY, Hwang IS, Eom JS, Cheong HJ, Bae WK, Park YH, et al. Prevalence and molecular epidemiology of vancomycin-resistant enterococci (VRE) strains isolated from animals and humans in Korea. Korean J Intern Med 2005;20:55-62.

3. Dutka-Malen S, Evers S, Courvalin P. Detection of glycopeptide resistance genotypes and identification to the species level of clinically relevant enterococci by PCR. J Clin Microbiol 1995;33:1434.

4. Delmas J, Robin F, Schweitzer C, Lesens O, Bonnet R. Evaluation of a new chromogenic medium, ChromID VRE, for detection of vancomycin-resistant enterococci in stool samples and rectal swabs. J Clin Microbiol 2007;45:2731-3.

5. Lee K, Jang SJ, Lee HJ, Ryoo N, Kim M, Hong SG, et al. Increasing prevalence of vancomycin-resistant Enterococcus faecium, expandedspectrum cephalosporin-resistant Klebsiella pneumoniae, and imipenem-resistant Pseudomonas aeruginosa in Korea: KONSAR study in 2001. J Korean Med Sci 2004;19:8-14.

6. Merquior VL, GonÇalves Neves FP, Ribeiro RL, Duarte RS, de Andrade Marques E, Teixeira LM. Bacteraemia associated with a vancomycin-resistant Enterococcus gallinarum strain harbouring both the vanA and vanC1 genes. J Med Microbiol 2008;57:244-5.

7. Grabsch EA, Ghaly-Derias S, Gao W, Howden BP. Comparative study of selective chromogenic (chromID VRE) and bile esculin agars for isolation and identification of vanB-containing vancomycinresistant enterococci from feces and rectal swabs. J Clin Microbiol 2008;46:4034-6

8. Kuch A, Stefaniuk E, Ozorowski T, Hryniewicz W. New selective and differential chromogenic agar medium, chromID VRE, for screening vancomycin-resistant Enterococcus species. J Microbiol Methods 2009;77:124-6.

9. Asir K, Wilkinson K, Perry JD, Reed RH, Gould FK. Evaluation of chromogenic media for the isolation of vancomycin-resistant enterococci from stool samples. Lett Appl Microbiol 2009;48:230-3.

10. Kim S, Sung H, Jeon HS, Park SJ, Park SH, Kim MN. Evaluation of a rapid enrichment-PCR method for the detection of vanA vancomycin-resistant enterococci in fecal specimens. Korean J Clin Microbiol 2007;10:44-8. (김솔잎, 성흥섭, 전홍선, 박숙자, 박상혁, 김미나. 대변검체에서 $v a n A$ 형 반코마이신 내성 장구균을 검출하기 위한 신속 증 균중합효소연쇄반응법 평가. 대한임상미생물학회지 2007;10:44-8.)

11. Ledeboer NA, Tibbetts RJ, Dunne WM. A new chromogenic agar medium, chromID VRE, to screen for vancomycin-resistant Enterococcus faecium and Enterococcus faecalis. Diagn Microbiol Infect Dis 2007;59:477-9.

12. Yoon YK, Sim HS, Kim JY, Park DW, Sohn JW, Roh KH, et al. Epidemiology and control of an outbreak of vancomycin-resistant enterococci in the intensive care units. Yonsei Med J 2009;50:637-43.

13. Palladino S, Kay ID, Flexman JP, Boehm I, Costa AM, Lambert EJ, et al. Rapid detection of $\operatorname{van} A$ and $\operatorname{van} B$ genes directly from clinical specimens and enrichment broths by real-time multiplex PCR assay. J Clin Microbiol 2003;41:2483-6.

14. Drews SJ, Johnson G, Gharabaghi F, Roscoe M, Matlow A, Tellier $\mathrm{R}$, et al. A 24-hour screening protocol for identification of vancomycinresistant Enterococcus faecium. J Clin Microbiol 2006;44:1578-80.

15. Hsueh PR, Teng LJ, Pan HJ, Chen YC, Wang LH, Chang SC, et al. Emergence of vancomycin-resistant enterococci at a university hospital in Taiwan: persistence of multiple species and multiple clones. Infect Control Hosp Epidemiol 1999;20:828-33.

16. Sung HS, Yun KA, Kim MN, Pai CH. An Enterococcus gallinarum strain carrying both vanA and vanC1 genes. Korean J Clin Pathol 2002;22:31-3. (성홍섭, 윤경아, 김미나, 배직현. vanA 유전자와 vanC1 유 
전자를 동시에 가진 Enterococcus gallinarum 1예. 대한임상병리학회지 2002;22:31-3.)

17. Park IJ, Lee WG, Shin JH, Lee KW, Woo GJ. VanB phenotype-vanA genotype Enterococcus faecium with heterogeneous expression of teicoplanin resistance. J Clin Microbiol 2008;46:3091-3. 